Boletín de la Sociedad Geológica Mexicana

VOLUMEN 62, NÚM. 2, 2010, P. 263-279

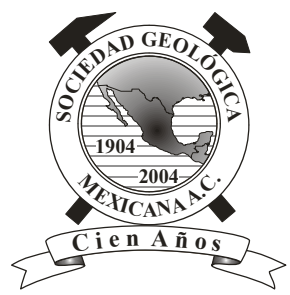

\title{
On some Panamerican Cretaceous crabs (Decapoda: Raninoida)
}

\author{
Francisco J. Vega ${ }^{1, *}$, Torrey Nyborg ${ }^{2}$, Greg Kovalchuk ${ }^{3}$, Javier Luque ${ }^{4,5}$, Alexis Rojas- \\ Briceño ${ }^{6}$, Pedro Patarroyo ${ }^{6}$, Héctor Porras-Múzquiz ${ }^{7}$, Adam Armstrong ${ }^{8}$, Hermann \\ Bermúdez ${ }^{9}$, and Luis Garibay ${ }^{10}$ \\ ${ }^{1}$ Instituto de Geología, UNAM, Ciudad Universitaria, México, D.F., Mexico. \\ 2 Department of Earth and Biological Sciences, Loma Linda University, Loma Linda CA, 92350, USA. \\ 31401 Chinook Street, The Dalles, OR 97058, USA. \\ ${ }^{4}$ Smithsonian Tropical Research Institute. Center for Tropical Paleoecology and Archaeology. Apartado Postal 0843-03092, Balboa, \\ Ancon, Panama. \\ ${ }^{5}$ Département de sciences biologiques, Université de Montréal, Montréal QC, Canada. \\ ${ }^{6}$ Departamento de Geociencias, Universidad Nacional de Colombia, A. A. 14490, Bogotá, Colombia. \\ ${ }^{7}$ Museo de Múzquiz A. C., Zaragoza 209, Múzquiz, Coahuila, 26340, Mexico. \\ 8306 Hilltop Road, Keene, TX, 76059, USA. \\ ${ }^{9}$ Carrera 57 No 134-20, torre 3 Apto 1004. Bogotá D.C., Colombia. \\ ${ }^{10}$ Unidad Académica de Ciencias de la Tierra, UAG, Exhacienda de San Juan Bautista S/N, Taxco el Viejo, Guerrero, 40200, Mexico. \\ *vegver@servidor.unam.mx
}

\begin{abstract}
Decapod crustacean specimens recently collected from new and previously reported localities of USA, Mexico, and Colombia, as well as a review of species of uncertain affinity, add important information to complete the descriptions and paleobiological knowledge of some Cretaceous primitive crabs. The stratigraphic range for the genus Cenomanocarcinus is formally extended from the upper Albian to Campanian, based on occurrences from Colombia, Oklahoma and Mexico. Specimens of Cenomanocarcinus vanstraeleni from the Turonian of Mexico and Colombia include features not described previously for this species, such as variation in the shape and ornament of chelae. Necrocarcinus renfroae is here included in the genus Cenomanocarcinus, based on features of dorsal and ventral carapaces, as well as shape of pereiopods, and its occurrence is documented from the upper Albian of Colombia. Orithopsis tricarinata is reported for the first time in America from upper Albian deposits of Oregon and Colombia; the shape of the sternum confirms close affinities with the Cenomanocarcinidae and the family Orithopsidae is here included in the section Raninoida and restricted to the genus Orithopsis.
\end{abstract}

Keywords: Crustacea, Raninoida, Cretaceous, North America, South America.

\section{Resumen}

Crustáceos decápodos colectados recientemente en localidades nuevas y previamente reportadas de EUA, México y Colombia, así como una revisión a especies de afinidad incierta, proveen información importante para complementar descripciones y conocimiento paleobiológico de algunos cangrejos primitivos cretácicos. El alcance estratigráfico del género Cenomanocarcinus es formalmente extendido del Albiano superior al Campaniano en Colombia, Oklahoma y México. Nuevos ejemplares de Cenomanocarcinus vanstraeleni del Turoniano de México y Colombia incluyen características no reportadas previamente para esta especie, tales como variación en el tamaño y forma de las quelas. Necrocarcinus renfroae es incluido en el género Cenomanocarcinus, con base en la morfología dorsal y ventral del caparazón, así como en la morfología de los pereiópodos y se documenta su presencia en el Albiano superior de Colombia. Orithopsis tricarinata es reportada por vez primera en América, en depósitos del Albiano superior de Colombia y Oregon, 
EUA; la morfología del esternón confirma su afinidad con la familia Cenomanocarcinidae y la familia Orithopsidae es aquí incluida en la sección Raninoida y restringida al género Orithopsis.

Palabras clave: Crustacea, Raninoida, Cretácico, Norteamérica, Sudamérica.

\section{Introduction}

This report adds important information to the knowledge of several decapod crustacean specimens collected from Cretaceous localities of the United States of America (USA), Mexico and Colombia, which support interpretations recently discussed by Guinot et al. (2008) for the family Cenomanocarcinidae Guinot, Vega and Van Bakel, 2008. Additional data are provided for stratigraphic range, morphological variation, and paleobiogeographic distribution of some primitive Cretaceous crabs from the Americas. Cenomanocarcinus vanstraeleni Stenzel, 1945, known from the Upper Cretaceous of southeastern USA, Mexico and Colombia, is reported from upper Albian strata of Colombia. A single specimen of Cenomanocarcinus sp. is reported from the Campanian of Guerrero, Mexico. These records allow the stratigraphic range of $C$. vanstraeleni to be extended to the upper Albian, and Cenomanocarcinus to the Campanian in America. One nearly complete specimen from the upper Albian Simití Formation of Colombia is identical with Cenomanocarcinus renfroae (Stenzel, 1945), containing impressions of most pereiopods; P4 are slightly reduced, have flat propodi and dactyli, and P5 are much reduced. Its sternum reveals close affinity to the genus Cenomanocarcinus. Several specimens of Orithopsis tricarinata (Bell, 1863) from the upper Albian Hudspeth Formation of Oregon represent the first record in America for that species; a complete sternum is preserved in one specimen, supporting affinities with the family Cenomanocarcinidae Guinot, Vega and Van Bakel, 2008. Examination of the type specimen of Necrocarcinus olssoni (Rathbun, 1937), from the Lower Cretaceous of Colombia, reveals that it actually is a specimen of Orithopsis tricarinata (Bell, 1863).

\section{Localities}

\subsection{Localities in Mexico}

\subsubsection{Eagle Ford Formation, Coahuila}

A series of quarries is exposed in the region north of Múzquiz, northwest of Coahuila, Mexico. The quarries consist of limestones and marls of late Turonian to early Coniacian age (Stinnesbeck et al., 2005). These deposits contain plant remains, planktic foraminifera, ammonoids, inoceramid bivalves, crustaceans, fishes, marine reptiles, and a pterosaur. Vega et al. (2007) provided a map and stratigraphic section for Turonian outcrops that yielded numerous specimens of Cenomanocarcinus vanstraeleni, whose exceptional preservation helped clarify the podotreme affinity of this species, and to erect a new family (Guinot et al., 2008). Herein we include recently discovered specimens, which further help complete the morphological features of this species.

\subsubsection{Mexcala Formation, Guerrero}

One specimen of Cenomanocarcinus sp. was collected in sediments of the Mexcala Formation, within shallow marine light brown siltstones and calcareous sandstones near the town of Zoquiapa in northeastern Guerrero State, Mexico. At this locality, a composite section of $25 \mathrm{~m}$ contains several species of Campanian gastropods and bivalves. This fossiliferous outcrop was previously reported by Fraaije $e t$ al. (2006) as locality IGM-3557, who published a locality map and stratigraphic section.

\subsection{Localities in Colombia}

\subsubsection{Upper San Gil Formation, Cordillera Oriental, Department of Boyacá}

The Villa de Leiva area (Cordillera Oriental, Department of Boyacá), located $127 \mathrm{~km}$ northeast of Bogotá, is one of the most studied fossiliferous localities in Colombia (Figure 1). Ammonites, other mollusks, echinoids, fishes, marine reptiles, and other fossil groups have been reported from Cretaceous strata of this region (Acosta et al., 1979; Bürlg, 1954; Etayo-Serna, 1968, 1979; Jerez-Jaimes and Narváez-Parra, 2001; Patarroyo, 2004; among others). A sole specimen of Cenomanocarcinus vanstraeleni was collected from the middle-upper portion of the Upper San Gil Formation, near the Sáchica - Puente Samacá highway. The Upper San Gil Formation consists of a lower 230 m-thick segment of mudstones with interstratified horizons of sandstone and limestone and fossiliferous beds that contain gastropods and bivalves. The upper segment of the Upper San Gil Formation is a 390 m-thick unit of darkgray shales, including clay nodules. Ammonites are the most common fossil found in these deposits. The age for the Upper San Gil Formation has been defined as Albian (Etayo-Serna et al., 1986). The section from which the specimen herein described was collected is relatively near the Albian/Cenomanian boundary (Figure 2). 


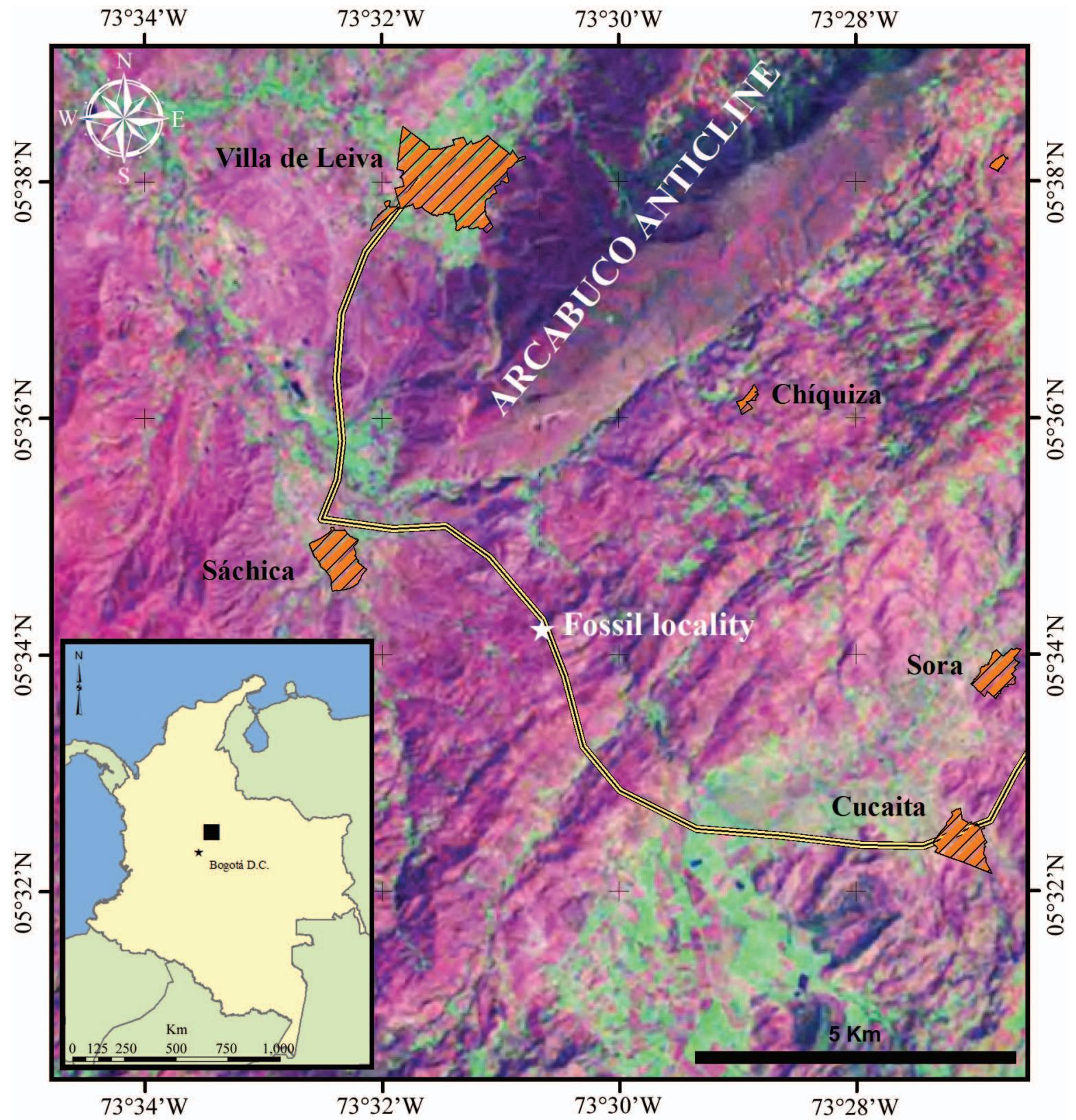

Figure 1. Location of outcrop where specimen INGEOMINAS-JCR-1 of Cenomanocarcinus vanstraeleni was collected. Upper San Gil Formation outcrop near Villa de Leiva, Cordillera Oriental, Department of Boyacá, Colombia.

\subsubsection{Simití Formation, boundary between Cundinamarca and Boyacá Departments}

The specimen herein described as Cenomanocarcinus renfroae was collected about $100 \mathrm{~km}$ north of Bogotá, between the Departments of Cundinamarca and Boyacá (Figure 3), in upper Albian to Cenomanian rocks of the Simití Formation (Petters, 1954; Ward et al., 1973; EtayoSerna et al., 1986). The Simití Formation is composed of $250-650 \mathrm{~m}$ slightly calcareous black to gray shales, with calcareous concretions (several meters in diameter) with thin interstratified layers of sandstone and gray limestone that are argillaceous and fossiliferous (Figure 4). Near the top of the unit, thin conglomeratic layers with phosphatic nodules and fish teeth occur (Etayo-Serna et al., 1986).

\subsubsection{San Rafael Formation, Samacá and Pesca, \\ Department of Boyacá}

Vega et al. (2007) described details of the stratigraphy, paleoenvironments, and localities that yielded crustacean specimens in the Turonian San Rafael Formation of Colombia (Patarroyo and Rojas-Briceño, 2007). Several new specimens of Cenomanocarcinus vanstraeleni have been collected, and they contain details not described previously for this species. In particular, slender and spiny 


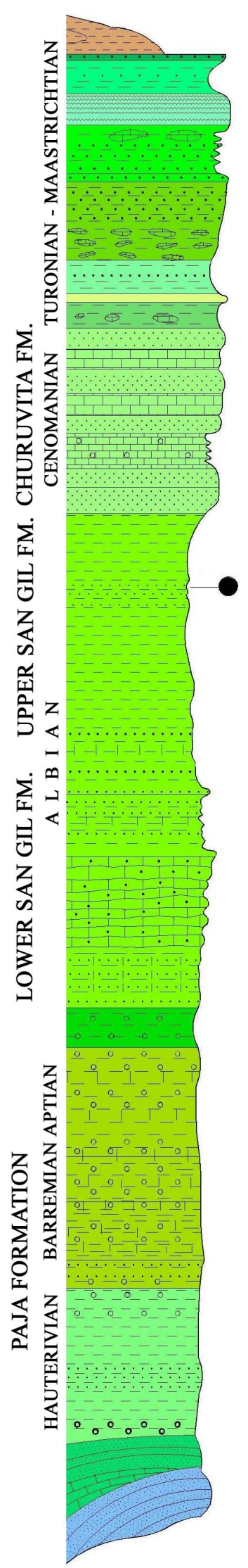

Figure 2. Composite stratigraphic section, with position of fossil locality where specimen INGEOMINAS-JCR-1 of Cenomanocarcinus vanstraeleni was collected. chelae are observed on several small specimens. This feature may be related to juvenile stages, or sexual dimorphism.

\subsubsection{Paja Formation, Samacá and Pesca, Department of Boyacá}

The description given by Rathbun (1937, p. 27) for the locality where the specimen that was originally identified as Dakoticancer olssoni is as follows: "Colombia: Curití, Departamento de Santander del Sur, near junction of branch road leading to the village of Curití, Eastern Cordillera, from the main auto road from San Gil to Bucaramanga." The locality is found $230 \mathrm{~km}$ NE of Bogotá, Colombia, where rocks of the Paja Formation crop out (Figure 5). The Paja Formation was originally described by Wheeler in Morales et al. (1958) as composed of fossiliferous blue to gray shales, intercalated with yellow-gray, fine-grained sandstones and thin gray limestone beds (Royero and Clavijo, 2001). The age for the Paja Formation has been considered as early Barremian to early Aptian (Etayo-Serna et al., 1986), but recent findings of ammonites and other mollusks in the area of the locality reported by Rathbun (1937) suggest that its age extends to the upper Albian (F. Etayo-Serna, personal communication).

\subsection{Localities in USA}

\subsubsection{Hudspeth Formation, Oregon}

Cretaceous sedimentary rocks within the Mitchell inlier of central Oregon include the Albian Hudspeth Formation (marine mudstone and turbidites) and the Cenomanian Gable Creek Formation (submarine-fan conglomerate and sandstone; see Dorsey and Lenegan, 2007, for detailed description). The Hudspeth Formation was defined by Wilkinson and Oles (1968) whom divided the formation into a basal Member (Khb), main Mudstone Member (Kh1), and a series of stratigraphically higher mudstone members (Kh2 to Kh11) with interbedded units of the Gable Creek Formation. Dorsey and Lenegan (2007) followed the stratigraphic subdivision, but defined a higher unit of mudstone (Khm) instead of the multiple members (Kh2 to Kh11 of Wilkinson and Oles, 1968). The Main Mudstone Member (Kh1) consists of dark gray to black mudstone with minor shale units (Dorsey and Lenegan, 2007). Calcitic concretions containing mainly ammonites with occasional fossil crabs are common within the lower and upper portions of this member as mapped by Dorsey and Lenegan (2007, figs. 2, 3). Ammonites collected from the Main Mudstone Member range from early to late Albian (112-99 Ma) (McKnight, 1964; Kleinhans et al., 1984; Dorsey and Lenegan, 2007). Based upon micropaleontologic data, the Hudspeth Formation deposits represent outer neritic to upper bathyal water depths (Kleinhans et al., 1984) with slow deposition in a relatively sediment-starved marine basin (Kleinhans et al., 1984; Wilkinson and Oles, 1968).

The Mitchell Inlier is a small Cretaceous outcrop within the larger Ochoco basin, which is believed to be part of the 




Figure 3. Location of outcrop where specimen INGEOMINAS-JFO-1 of Cenomanocarcinus renfroae was collected. Upper Albian Simití Formation, Department of Boyacá and Cundinamarca, Colombia.

Cretaceous Great Valley forearc basin in California and the Hornbrook basin of southern Oregon (Wilkinson and Oles, 1968; Oles and Enlows, 1971; Kleinhans et al., 1984; Nilsen, 1986; Dorsey and Lenegan, 2007). The only species of crab previously reported from the Hudspeth Formation is Eucorystes platys Schweitzer and Feldmann, 2001. Five specimens of Orithopsis tricarinata were collected as eroded calcitic concretions from the SE $1 / 4$, Section 23, T115N, R21E of the 1:48,000 geologic map of the Mitchell Quadrangle, Oregon, mapped as part of the Main Mudstone Member (Kh1) by Wilkinson and Oles (1968). Detailed geology of the Cretaceous sedimentary rocks of the Mitchell Inlier, including stratigraphic columns, is illustrated and discussed by Dorsey and Lenegan (2007).

\subsubsection{Paw Paw Formation, Texas}

The Paw Paw Formation (Hill, 1894) is predominately a siliciclastic unit within the limestone-dominated upper Albian to lower Cenomanian Washita Group (Kennedy et al., 2005). The Paw Paw Formation correlates with the late Albian European standard ammonite Mortoniceras (Subschloenbachia) rostratum Subzone (Kennedy, 2004; 


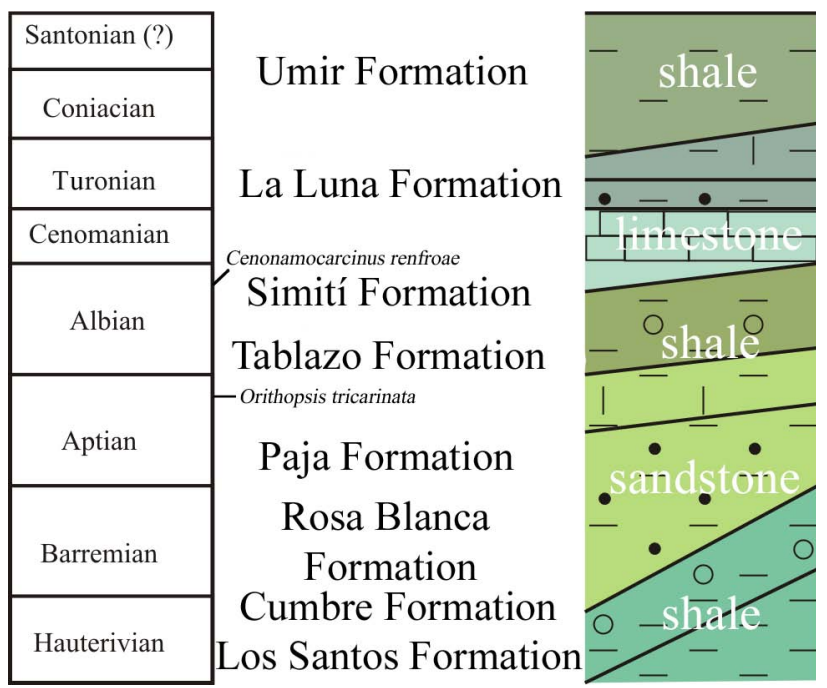

Figure 4. Cretaceous composite stratigraphic section, with position of fossil localities where specimen INGEOMINAS-JFO-1 of Cenomanocarcinus renfroae and specimen USNM 495104 of Orithopsis tricarinata were collected. Modified from Morales et al. (1958) and Barrero et al. (2007).

Kennedy et al., 2005). Within Tarrant County, Texas, the Paw Paw Formation consists of approximately $8 \mathrm{~m}$ of brown arenaceous clay with cross-bedded sandstone and ironstone concretions that crop out along a narrow northsouth band across the county (Root, 1975; Kennedy, 2004). The Paw Paw Formation is highly fossiliferous in marine invertebrates (Adkins, 1918; Hendricks, 1967; Blake and Reid, 1998) and vertebrates (Lee, 1994, 1996; Siverson et al., 2007). Fossil decapod crustaceans have been previously reported by Rathbun (1935), Hendricks (1967), Schweitzer Hopkins et al. (1999), and Haj and Feldmann (2002). The Necrocarcinus renfroae (Rathbun, 1935) specimen was collected from an outcrop of clay that weathers reddishbrown and is referable to the Paw Paw Formation (Figure 6; McGowen et al., 1972). The locality preserves abundant micro ammonites with occasional decapod crustaceans.

\section{Repository}

Specimens herein reported are deposited in the following collections: Colección Nacional de Paleontología, Instituto de Geología, UNAM, Mexico, under acronym IGM; Colección Paleontológica, Museo de Múzquiz, Múzquiz, Coahuila, Mexico, under acronym MUZ; Museo Geológico José Royo y Gómez, Bogotá, Colombia, under acronym INGEOMINAS; Colecciones Paleontológicas del Departamento de Geociencias, Universidad Nacional de Colombia, Bogotá, Colombia, under acronym UN-DG; Burke Museum of Natural History and Culture, University of Washington,

Seattle, Washington, under acronym UWBM; Texas Natural Science Center, Austin, Texas (previously
Vega et al.

Paleontological Collection of the Bureau of Economic Geology, University of Texas), under acronym NPL; National Museum of Natural History, Smithsonian Institution, Washington, DC, under acronym USNM; New Mexico University, Paleontological Collection, under acronym UNM; Museo Civico di Storia Naturale di Milano, under acronym MSNMi. Abbreviations include P2-P5 for second to fifth pereiopods.

\section{Systematic paleontology}

Infraorder Brachyura Latreille, 1802

Section Raninoida De Haan, 1839

Family Cenomanocarcinidae Guinot, Vega and Van Bakel, 2008

Genus Cenomanocarcinus Van Straelen, 1936

Type species. Cenomanocarcinus inflatus Van Straelen, 1936 by original designation

Cenomanocarcinus vanstraeleni Stenzel, 1945

Figures 7; 8.1-8.5

Cenomanocarcinus vanstraeleni Stenzel, 1945, p. 447450, text-fig. 15; Förster, 1968, Abb. 4; Finsley, 1989, p. 98, 99, pl. 78, photos 307, 308; Bishop, Brannen, Hill, Meyer, Pike, and Sampson, 1992, fig. 7c; Vega, Nyborg, Rojas-Briceño, Patarroyo, Luque, Porras-Múzquiz, and Stinnesbeck, 2007, p. 412, figs. 7.2 - 7.9, 8.1 - 8.11, 9.1 - 9.5; Patarroyo and Rojas-Briceño, 2007, p. 92-93, pl. 2, figs. 1 - 4; Guinot, Vega and Van Bakel, 2008, p. 11, figs. 2, 3A-D, 3F, 4, 5.

Necrocarcinus vanstraeleni (Stenzel, 1945); Kues, 1980, p. 862-864, text-fig. 1 .

Necrocarcinus (Cenomanocarcinus) vanstraeleni (Stenzel, 1945)?; Toolson and Kues, 1996, p. 114-115, fig. 1.5.

Ophthalmoplax spinosus Feldmann, Villamil and Kauffman, 1999, p. 96, figs. 3.1, 3.2, 4.1, 4.2.

Cenomanocarcinus sp.; Guinot, Vega and Van Bakel, 2008, p. 694, fig. 3E.

Supplementary description. A complete dorsal carapace description of Cenomanocarcinus vanstraeleni can be found in Stenzel (1945). Vega et al. (2007) expanded the description to include details of pereiopods, female abdomen and sternum. Guinot et al. (2008) provided the most complete description of the sternum and venter of both sexes for this species. Minor additions are given below, including details observed on chelipeds of Turonian specimens from Colombia.

Carapace subovate transversely; anterolateral margin with five to six small spines, not including the outer orbital spine; orbits small, subcircular, with two strong fissures on orbital margin; front tricuspate, projected; dorsal carapace marked by transverse and longitudinal ridges, which bear variable number of tubercles; tubercles lost when cuticle is not preserved, except for posterior tubercle in posterolateral ridges, which is strong. Female sternite 1 not seen; 


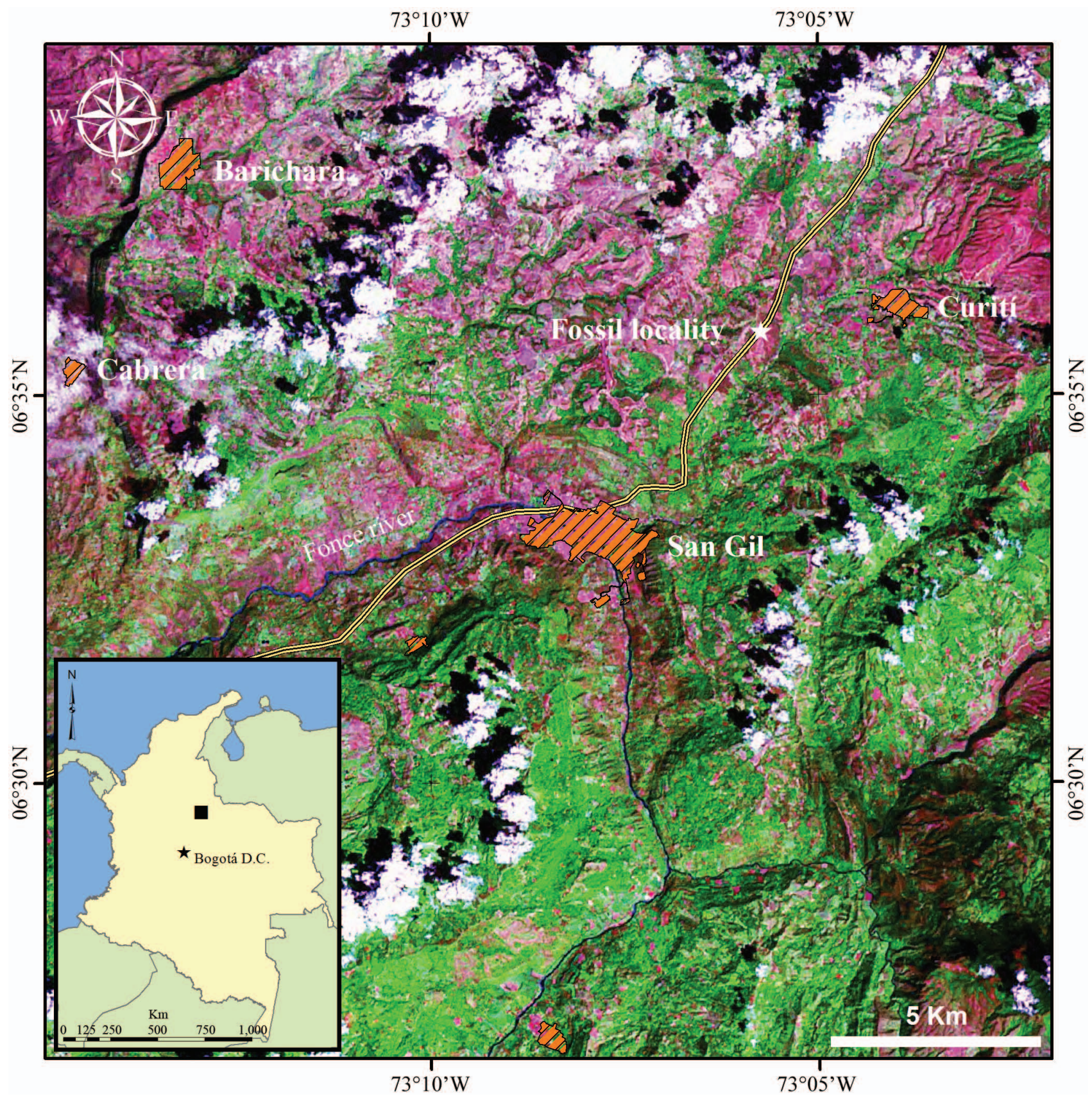

Figure 5. Location of outcrop where specimen USNM 495104 of Orithopsis tricarinata was collected. Upper Aptian Paja Formation near Curití, Department of Santander, Colombia.

sternite 2 inverted triangle; sutures $2 / 3$ not clear; sternite 3 subtrapezoidal, nearly three times as wide and four times as long as sternite 2 ; sutures $3 / 4$ well defined; sternite 4 widest, with inclined, ovate external margins, one-third wider and about same length as sternite 2; sutures $4 / 5$ well defined; sternite 5 similar outline as sternite 4 , but one-third shorter and narrower; sutures $5 / 6$ well-defined, half the width of precedent sutures; sternite 6 one-third the width and length of sternite 5 , external portions inverted-triangular; sternite 7 not seen.
Outer surface of left palm with a medial longitudinal row of tubercles. Some female specimens from Colombia possess long, slender chelipeds that nearly equal carapace width; both fingers downturned, lower margin of dactyl with several, evenly spaced long, sharp spines of similar size; upper and lower margins of fixed finger also with sharp spines. Male abdomen shorter than female abdomen, with rounded terminal margin of telson. Female abdomen three-fourths the length of carapace, abdominal segment 1 the smallest, subtrapezoidal inverted, two-thirds maximum 


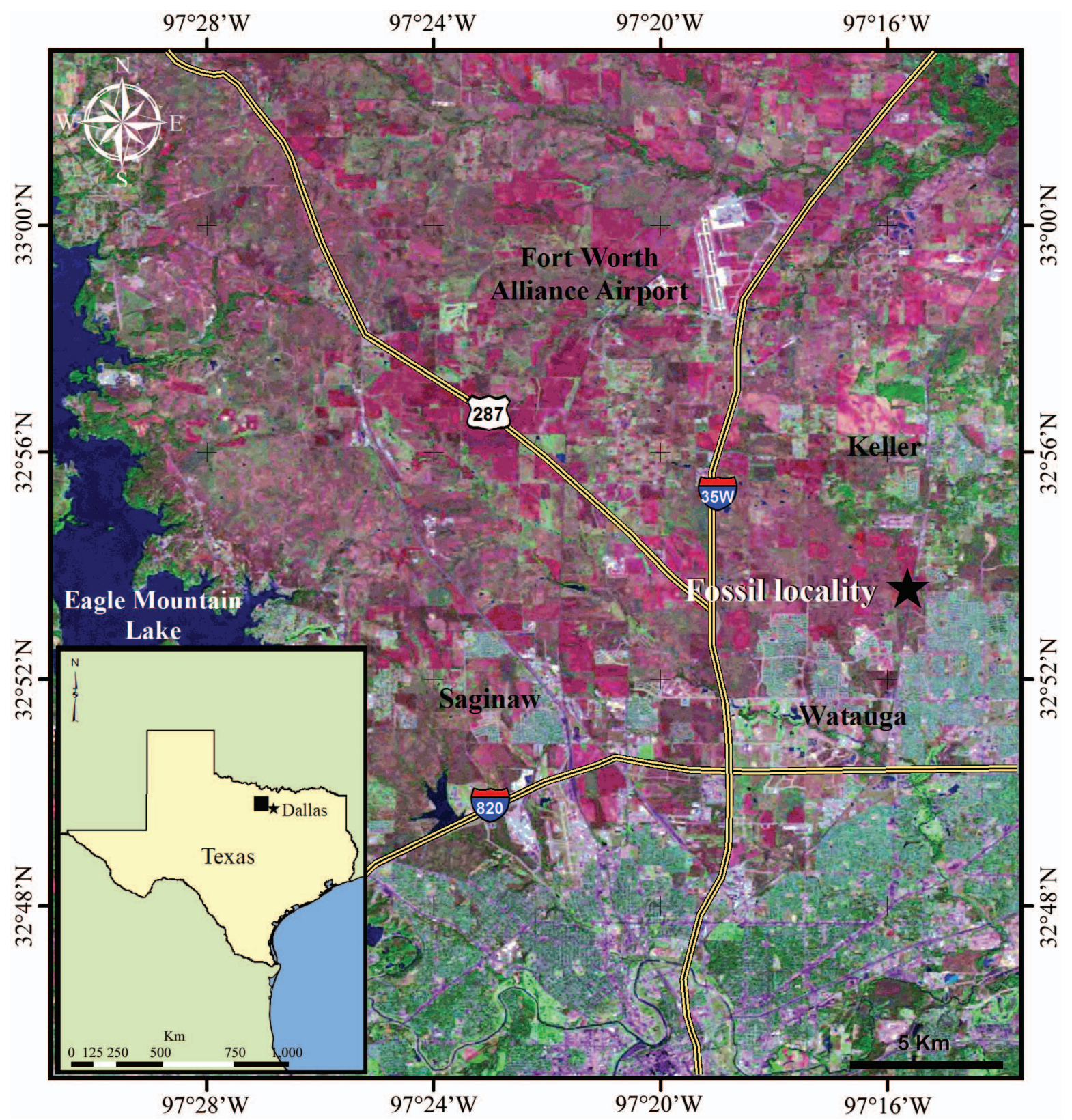

Figure 6. Location of outcrop where specimen NPL31182 of Cenomanocarcinus renfroae was collected. Upper Albian, Paw Paw Formation, Texas.

width of abdomen; abdominal segment 2 of similar shape but one-third longer and wider than previous segment, with a median transverse ridge; abdominal segment 3 subrectangular, bearing inclined lateral margins, with median transverse ridge; abdominal segment 4 very similar to segment 3 , but slightly shorter, with median transverse ridge; abdominal segment 5 subrectangular, with slightly rounded lateral margins, with median transverse ridge; abdominal segment 6 nearly square, twice the length of segment 5, with central transverse ridge and two small inclined ridges at posterolateral corners; telson nearly triangular.

Material examined. Hypotypes IGM-6112; MUZ-
571 to MUZ-573 and MUZ-617; INGEOMINAS-JCR-1, INGEOMINAS-JLC-0010, INGEOMINAS-JLC-0019, INGEOMINAS-JLC-0112, INGEOMINAS-JLC-0032; UN-DG-CR-014 to UN-DG-CR-017.

Occurrence. Turonian, Eagle Ford Formation, Texas; lower-middle Turonian, Eagle Ford Group, Rancho El Pilote, Coahuila, Mexico; upper Albian, Upper San Gil Formation, Cordillera Oriental, Department of Boyacá, Colombia; lower Turonian, San Rafael Formation, Pesca, Department of Boyacá, Colombia.

Measurements (in mm). Hypotype IGM-6112 carapace length $=28.2$, carapace width $=35.8 ;$ MUZ-571 carapace length $=22.3$, carapace width $=26.7 ;$ MUZ-572 

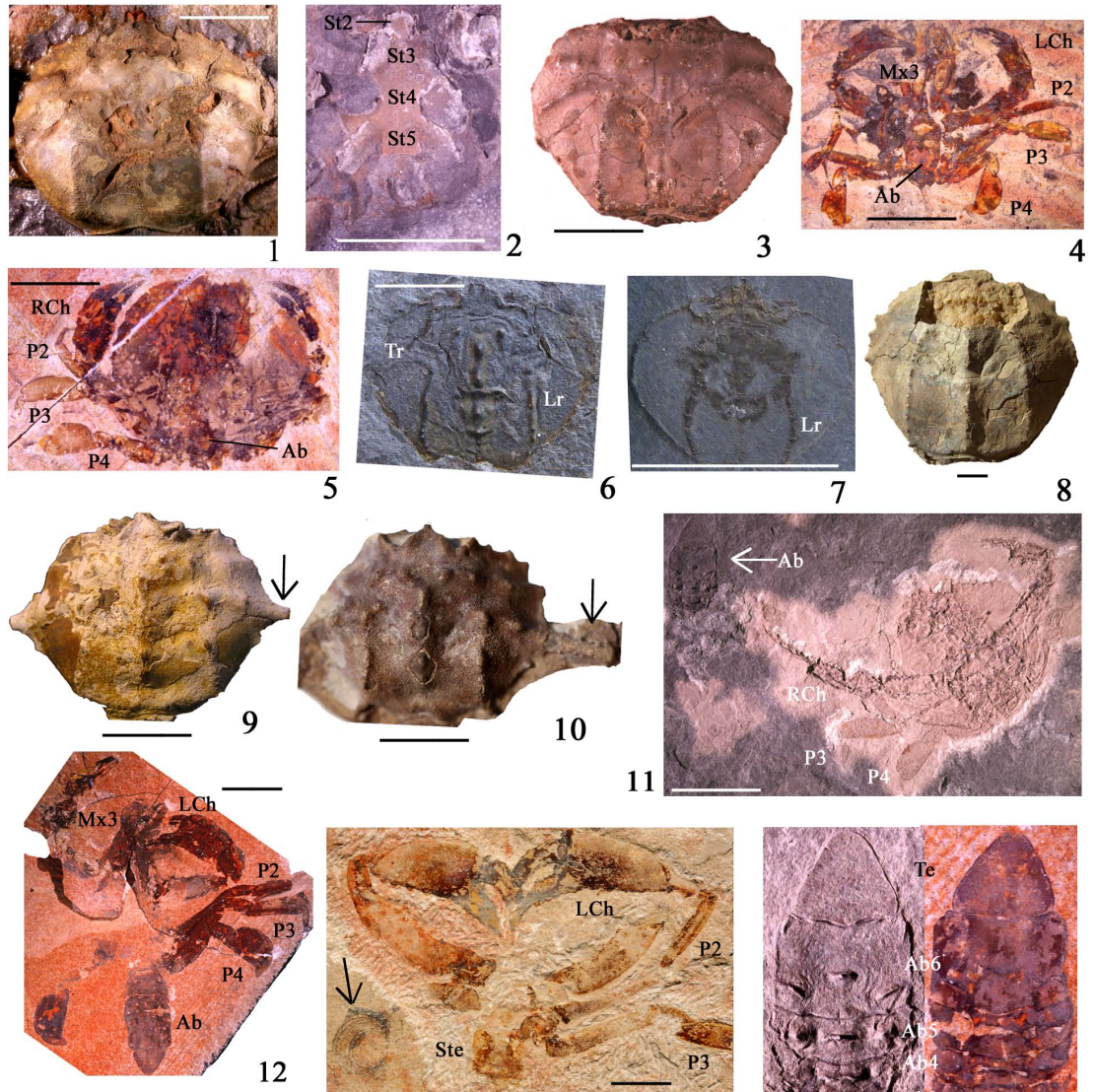

12
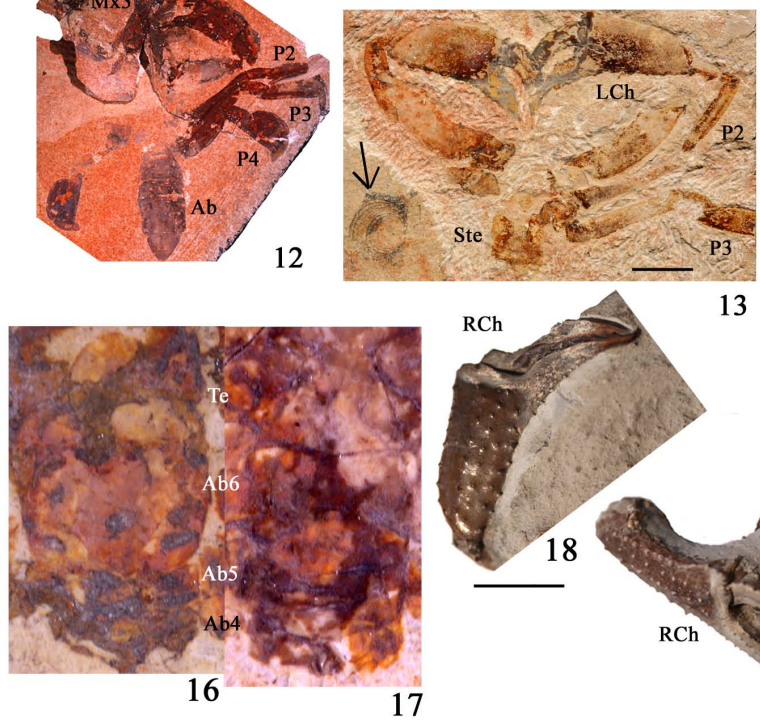

$13 \quad 14$

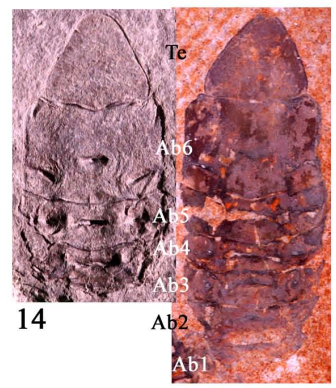

15

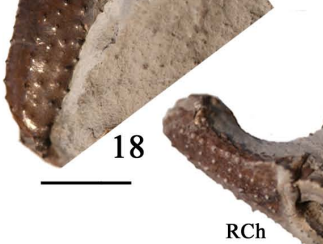

17

Figure 7. Cenomanocarcinus vanstraeleni Stenzel, 1945. 1. Hypotype INGEOMINAS-JCR-1, dorsal carapace, female, upper Albian, Upper San Gil Formation, near Villa de Leiva, Department of Boyacá, Colombia. 2. Sternum of same specimen, also figured in Guinot et al., 2008, fig. 3E, as Cenomanocarcinus sp., note sternites 2 to 5 (St2-St5). 3. Hypotype IGM-6112, dorsal carapace, Cenomanian, Eagle Ford Group, Texas, USA. 4. Hypotype MUZ-571, ventral view, male, Turonian, Eagle Ford Group, Coahuila, Mexico, note left cheliped (LCh), second to fourth pereiopods (P2-P4), third maxillipeds (Mx3) and abdomen (Ab). 5. Hypotype MUZ-572, male, ventral view, Turonian, Eagle Ford Group, Coahuila, Mexico, note right cheliped $(\mathrm{RCh})$, second to fourth pereiopods (P2-P4) and abdomen (Ab). 6. Hypotype INGEOMINAS-JLC-0010, dorsal carapace, lower Turonian, San Rafael Formation, Colombia, note longitudinal and transverse ridges (Lr, Tr, respectively). 7. Hypotype INGEOMINAS-JLC-0019, dorsal carapace, lower Turonian, San Rafael Formation, Colombia, note longitudinal ridges (Lr). 8. Specimen from Turonian Mancos Shale, New Mexico; hypotype 3938, University of New Mexico, Paleontological Collection. 9. Dorsal view of specimen in private collection, arrow indicates right anterolateral spine. 10. Specimen at the National Museum of Natural History, Smithsonian Institution, Eagle Ford Formation, Accession number 2009820, arrow indicates extremely long right anterolateral spine. 11. Hypotype UN-DG-CR-014, ventral view, female, lower Turonian, San Rafael Formation, Colombia, note arrow pointing anterior portion of abdomen $(\mathrm{Ab})$, right cheliped (RCh) and third and fourth pereiopods (P3, P4). 12. Hypotype MUZ-573, ventral view, female, Turonian, Eagle Ford Group, Coahuila, Mexico, note detached abdomen $(\mathrm{Ab})$ on posterior portion of carapace, left cheliped (LCh), third maxillipeds (Mx3) and second to fourth pereiopods (P2-P4). 13. Hypotype MUZ-617, ventral view, large female, Turonian, Eagle Ford Group, Coahuila, Mexico, note inoceramid bivalve preserved next to specimen, left cheliped ( $\mathrm{LCh}$ ), anterior portion of sternum (Ste) and second and third pereiopods (P2, P3). 14. Close up of female abdomen next to hypotype UN-DG-CR-014, figure 6.11. 15. Close up of female abdomen of hypotype MUZ-573, figure 6.12, note abdominal segments 6 to 1 (Ab6-Ab1) and telson (Te). 16. Close up of male abdomen of hypotype MUZ-572, figure 6.4. 17. Close up of male abdomen of hypotype MUZ-571, figure 6.5, note abdominal segments 6 to 4 (Ab6-Ab4) and telson (Te). 18. Right chela (RCh) of specimen at the National Museum of Natural History, Smithsonian Institution, Eagle Ford Formation, accession number 2009820. 19. Ventral view of specimen at the National Museum of Natural History, Smithsonian Institution, Eagle Ford Formation, Accession number 2009820, note right and left chelae (RCh, LCh), as well as third maxillipeds $(\mathrm{Mx} 3)$. Scale bars $=1$ centimeter. 
carapace length $=22.1$, carapace width $=25.4 ;$ MUZ-573 $=$ carapace length $=34.7$, abdomen length $=22.9$, abdomen width $=10.1$; MUZ-617 $=$ carapace length $=45.7$, width 62.1; INGEOMINAS-JCR-1 carapace length $=32.2$, carapace width: 39.8; INGEOMINAS-JLC-0010 carapace length $=21.5$, carapace width $=27.7$; INGEOMINASJLC-0019 carapace length $=13.1$, carapace width $=$ 16.4; INGEOMINAS-JLC-0112, abdomen length $=19.4$, abdomen width $=13.2 ;$ INGEOMINAS-JLC-0032, left chela length $=14.2$, left chela width $=5.7 ;$ UN-DG-CR-014 carapace length $=26.6$, carapace width $=30.3$; UN-DGCR-015 right chela length $=18.2$, right chela width $=6.3$; UN-DG-CR-16 carapace length $=23.1$, carapace width $=30.3$; UN-DG-CR-17 carapace length $=20.9$, carapace width $=28.5$.

Discussion. Guinot et al. (2008) indicated differences in size and shape of abdomen and pereiopods as an expression of sexual dimorphism. Spinose chelipeds in some female specimens from the Turonian of Colombia (Figure 8.1 to 8.4) may be related to environmental stress, such as anoxia, previously interpreted for these sediments (Feldmann et al., 1999). An anterior portion of a female abdomen was preserved next to one specimen from the San Rafael Formation in Colombia (Figure 7.11, 7.15). The shape of this female abdomen is identical to that observed in articulated specimens of Cenomanocarcinus vanstraeleni from Múzquiz and Texas. Although preservation is not as good as in the type material, dorsal carapaces from the San Rafael Formation show the longitudinal and transverse ridges (Figure 7.9, 7.10), as well as the tricuspate front typical of $C$. vanstraeleni.

The stratigraphic range for Cenomanocarcinus vanstraeleni was reported to be upper Cenomanian to lower Turonian (Guinot et al., 2008). With the report of C. vanstraeleni from the Upper San Gil Formation, the stratigraphic range for this species is extended to the upper Albian. Ophthalmoplax spinosus from the Turonian of Colombia was synonymised with $C$. vanstraeleni by Vega et al. (2007). We concur.

Cenomanocarcinus oklahomensis (Rathbun, 1935) from the Albian Marietta Formation of Texas (Figure 8.5) is very similar to $C$. vanstraeleni, but more complete specimens are necessary to suggest a possible synonymy.

\section{Cenomanocarcinus renfroae (Stenzel, 1945) new combination}

Figure 8.6-8.12

Necrocarcinus renfroae Stenzel, 1945, p. 443, pl. 41, fig. 13; Guinot, Vega and Van Bakel, 2008, p. 698, figs. 8A-8D.

Emended diagnosis. Carapace small, longer than wide; orbits large; anterolateral margin with at least four spines; posterolateral margin long, smooth; posterior margin straight, about half the maximum width; dorsal carapace subdivided by three subparallel longitudinal tuberculated ridges, the middle one being longer; a short transverse ridge joining lateral ridges with posterior spine of anterolateral margins; cervical groove sinuous; sternum narrow; sternite 1 subcircular, small; sternite 2 inverted triangle; sternite 3 subtrapezoidal; sternite 4 the widest of all sternites, with inclined, ovate external margins; sternite 5 of about the same shape as sternite 4 ; sternite 6 one-third the width of sternite 5 ; sternite 7 one-third smaller than sternite 6 . Chelipeds robust, similar. P2 elongated. P3 elongated, slightly longer than P2. P4 one-third shorter than P3. P5 not clear but reduced, one-sixth the length of $\mathrm{P} 4$.

Description. Carapace small, subhexagonal, slightly longer than wide; anterolateral margin about half the length of carapace; posterolateral margin slightly longer than anterolateral margin; posterolateral margin straight, onethird maximum carapace width; carapace surface marked by three longitudinal, sharp ridges, middle ridge longest, reaches protogastric region, interrupted at level of urogastric region, but continues to cardiac region; lateral ridges parallel to middle ridge, extending from border of posterolateral and posterior margins to gastric area. Sternum narrow, sternite 1 subcircular, small; sternite 2 inverted triangle; sutures 2/3 not clear; sternite 3 subtrapezoidal, nearly four times as long as length of sternite 2; sutures $3 / 4$ well defined; sternite 4 widest of all, with inclined, ovate external margins, one-third wider and of about the same length of sternite 2; sutures $4 / 5$ well defined; sternite 5 of about the same shape as sternite 4, but one-third shorter and narrower than sternite 4; sutures $5 / 6$ well-defined, half the width of preceding sutures; sternite 6 one-third the width of sternite 5 and one-third longer than sternite 5 , external portions invertedtriangular; sutures 6/7 deeply impressed, sinuous; sternite 7 one-third smaller than sternite 6 , lateral portions ovate, inclined posteriorly. Chelipeds robust, similar in shape and size, palm subrectangular, with two longitudinal ridges seen on inner surface of left chela, dactylus curved, sharp, onefourth longer than palm, one-third its height. P2 elongated, merus rectangular, two-thirds the length of carapace, height one-sixth its own length; carpus subtriangular, one-fourth the length of merus, narrow at junction with merus, three times wider at junction with propodus; propodus elongated, one-third shorter than merus, lower margin straight, upper margin concave, narrow at junction with carpus, two times higher at junction with dactylus; dactylus lanceolate, half the length of propodus, distal tip sharp. P3 elongated, slightly longer than $\mathrm{P} 2$, but with the same proportions of articles, except dactylus which is longer than P2 dactylus. P4 onethird shorter than P3; merus rectangular, elongated, half the height of P3 merus; carpus subcampanulate, narrow at junction with merus, two-times higher at junction with propodus; propodus subcampanulate, one-third longer than carpus, slightly narrower at junction with carpus, one-third wider at junction with dactylus; dactylus lanceolated, nearly as long as propodus, lower margin curved, distal tip sharp. P5 not clear but reduced, one-sixth the length of P4, merus subrectangular, one-fourth the length of P4 merus and one-third its height; carpus subrectangular, nearly as long as merus; propodus sobovate, one-third shorter than 

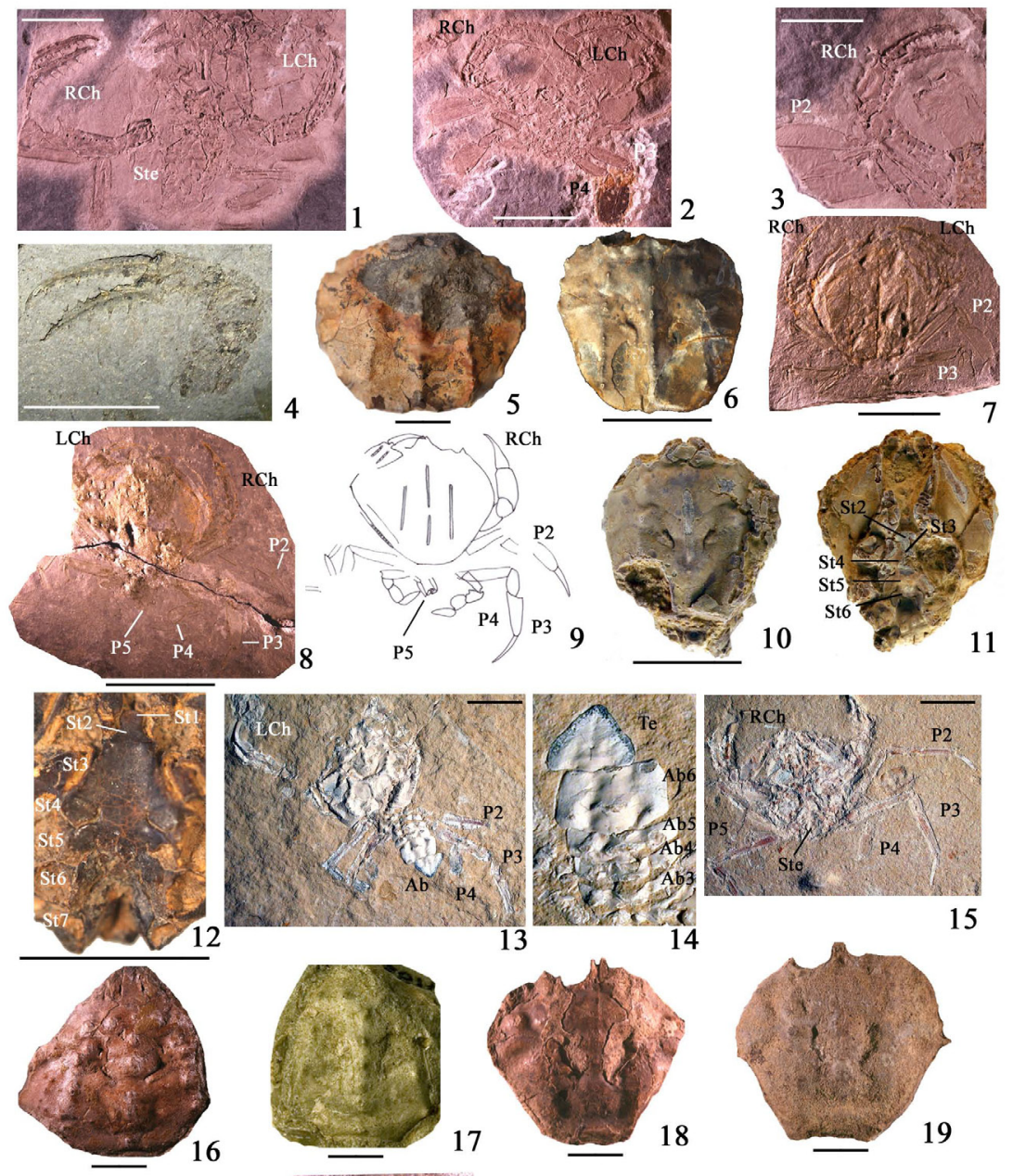

11
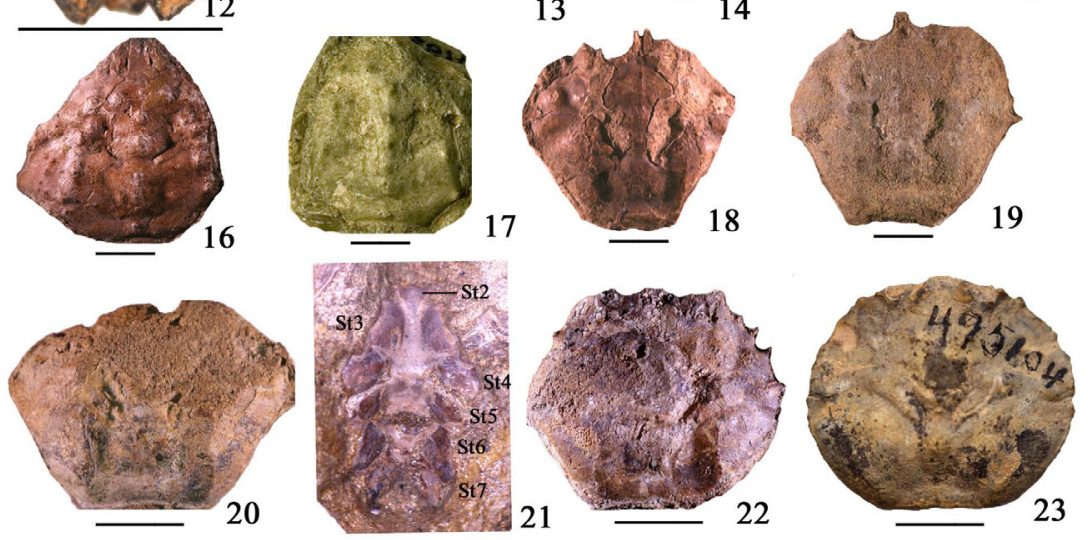

Figure 8. 1-5. Cenomanocarcinus vanstraeleni Stenzel, 1945. 1. Hypotype UN-DG-CR-015, female, ventral view, lower Turonian, San Rafael Formation, Colombia, note sternum (Ste) and spiny and slender dacylus and fixed finger of right and left cheliped (RCh, LCh). 2. Hypotype UN-DG-CR-16, female, ventral view, lower Turonian, San Rafael Formation, Colombia, note fourth pereiopod (P4) and spiny and slender dactylus and fixed finger of both chelae (RCh, LCh). 3. Hypotype UN-DG-CR-17, female, ventral view, lower Turonian, San Rafael Formation, Colombia, note third pereiopod (P3) and spiny and slender dactylus and fixed finger of right chela (RCh). 4. Hypotype INGEOMINAS-JLC-0032, lower Turonian, San Rafael Formation, Colombia, note spiny and slender dactylus and fixed finger of left chela. 5. Hypotype 73713, Albian, Marietta Formation of Denison Group, Oklahoma, National Museum of Natural History. 6-12. Cenomanocarcinus renfroae (Stenzel, 1945). 6. Holotype BEG-21093-A3, upper Albian, Paw Paw Formation (Tarrant County, Texas), Texas Natural Science Center, Austin (previously Paleontological Collection of the Bureau of Economic Geology, University of Texas). 7 , 8. Hypotype INGEOMINAS-JFO-759, dorsal impression of carapace, upper Albian, Simití Formation, limit between Departments of Cundinamarca and Boyacá, Colombia. 7. Counterpart, note second and third pereiopods (P2, P3) and right and left chelipeds (LCh, RCh). 8. Dorsal view of carapace, note right and left chelipeds (RCh, LCh) and second to fifth pereiopods (P2-P5). 9. Drawing of carapace of previous image. 10, 11. Hypotype NPL31182, upper Albian, Paw Paw Formation, Texas. 10. Dorsal view of carapace. 11. Ventral view of carapace, note sternum with sternites 2 to 6 (St2-St6). 12. Hypotype USNM 233978, close up of sternum, upper Albian, Paw Paw Formation, Texas, note sternum with sternites 1 to 7 (St1-St7). 13-15. Corazzatocarcinus hadjoulae (Roger, 1946), Cenomanian, Hgula, Lebanon. 13. Topotype MSNMi 26042a, dorsal view of carapace, note detached female abdomen (Ab), left cheliped $(\mathrm{LCh})$ and second to fourth pereiopods (P2-P4). 14. Close up to female abdomen, same specimen, note telson (Te) and abdominal segments 6 to 3 (Ab6Ab3). 15. Topotype MSNMi 24810a, ventral view of carapace, note anterior portion of sternum (Ste), right cheliped (RCh) and second to fifth pereiopods (P2-P5). 16. Cenomanocarcinus sp., hypotype IGM-6113, dorsal carapace, Campanian, Mexcala Formation, Guerrero, Mexico. 17. Cenomanocarcinus sp., hypotype USNM 418277, Upper Cretaceous (probably Turonian), Frontier Formation, Wyoming, USA. 18-23. Orithopsis tricarinata (Bell, 1863). 18. Hypotype UWBM 98678, dorsal carapace, upper Albian, Hudspeth Formation, Oregon, USA. 19. Hypotype UWBM 98679, dorsal carapace, upper Albian, Hudspeth Formation, Oregon, USA. 20. Hypotype UWBM 98678, partial dorsal carapace, upper Albian, Hudspeth Formation, Oregon, USA. 21. Sternum of same specimen, note sternites 2 to 7 (St2-St7). 22. Hypotype UWBM 98678, dorsal carapace, upper Albian, Hudspeth Formation, Oregon, USA. 23. Hypotype USNM 495104, dorsal view of carapace, upper Albian, Santander, Colombia. Scale bars $=1$ centimeter. 
carpus; dactylus unciform, half the height of propodus, one-third shorter.

Material examined. Holotype BEG-21093-A3; hypotypes INGEOMINAS-JFO-759, NPL31182 and USNM 233978.

Occurrence. Upper Albian, Simití Formation, limit between Departments of Cundinamarca and Boyacá, Colombia; upper Albian, Paw Paw Formation, Texas.

Measurements (in mm). Holotype BEG-21093-A3 carapace length $=16.4$, width $=18.1$; hypotypes INGEOMINAS-JFO-759 carapace length $=11.0$, width $=13.1 ;$ NPL31182 carapace length $=10.9$, width $=9.7$; USNM 233978 carapace length $=9.0$, width $=10.3$.

Discussion. Affinity of Necrocarcinus renfroae with Cenomanocarcinus was previously suggested by Förster (1968), Bishop (1986) and Schweitzer et al. (2003). Guinot et al. (2008) mentioned a deep branchiocardiac groove, larger orbits, and absence of an epibranchial ridge as features that preclude inclusion of Necrocarcinus renfroae in Cenomanocarcinus. However, sterna of two specimens reveal important similarities with sterna of species within Cenomanocarcinus. Specimens of $C$. renfroae are very small when compared with the mean size of Cenomanocarcinus spp. One possibility is that $C$. renfroae represents either a juvenile stage of $C$. vanstraeleni or sexual dimorphism, but more complete specimens need to be found to confirm this hypothesis.

The single Colombian specimen (Fig. 8.7, 8.8) has an elongated carapace with three longitudinal parallel ridges, features observed in specimens of Cenomanocarcinus renfroae from Texas. The robust chelae and elongated pereiopods 2 and 3 are similar to those present in specimens of C. vanstraeleni (Vega et al., 2007; Guinot et al., 2008), although reduced $\mathrm{P} 4$ are not typical of $C$. vanstraeleni. P4 observed in the specimen from the Simití Formation have certain similarities with the $\mathrm{P} 4$ seen in Corazzatocarcinus hadjoulae (Figure 8.13, 8.15; Roger, 1946), which shares with Cenomanocarcinus a similar shape of abdomen and sternum (Figure 8.14, 8.15), tricuspate front and tuberculated ridges on dorsal carapace, and should be included into the Cenomanocarcinidae. Although Guinot et al. (2008, p. 710) indicated that inclusion of the Cenomanocarcinidae within the subsection Raninoidia was supported by P4 expanded, with enlarged and flattened articles, features of $\mathrm{P} 4$ observed in Cenomanocarcinus renfroae and Corazzatocarcinus hadjoulae suggest that morphology and development of P4 may vary among members of the Cenomanocarcinidae.

\section{Cenomanocarcinus sp.}

Figure 8.16

Description. Carapace of medium size, subhexagonal, nearly as long as wide; cuticle with fine granules of uniform size; front projected, tricuspate; orbits narrow, semicircular, with two median fissures; posterior margin nearly straight, slightly concave medially; three longitudinal, parallel ridges on posterior two-thirds of carapace; four small transverse spines on protogastric region; mesogastric region with two longitudinally aligned spines; cardiac region with one spine on anterior portion; intestinal region with one central small spine; cervical groove deeply impressed; branchial lobes ovate, inclined toward central portion of carapace; urogastric region depressed; cardiac region with three medial, axially and evenly spaced spines; small, acute tubercle medially placed on intestinal region: transverse, arcuate branchial ridges with at least two sharp spines; posterolateral longitudinal ridges with six sharp spines; area between posterolateral and branchial ridges covered by small tubercles.

Material examined. Hypotype IGM-6113.

Occurrence. Campanian, Mexcala Formation, Zoquiapa, Guerrero, Mexico.

Measurements (in mm). Hypotype IGM-6113 carapace length $=44$, width $=45$.

Discussion. The specimen from Guerrero differs from the other known species described for the genus in having fewer tubercles on the lateral longitudinal ridges, the presence of tubercles on the posterolateral area between the left lateral ridge and the posterolateral margin, and the branchial lobes are much more strongly marked. The Mexican specimen preserves the typical tricuspate front, left and right posterior longitudinal ridges, a median longitudinal ridge with six tubercles, and a left metabranchial region, with a portion of the transverse branchial ridge. It has well defined epibranchial lobes, and a relatively deep transverse posterior groove parallel to the posterior margin. More complete specimens are needed in order to define with certainty the specific placement of this specimen. However, preservation of the only specimen is too incomplete to assign to species level at this time. Reliable reliably

The specimen of Cenomanocarcinus sp. found in Campanian sediments from Southern Mexico has a similar shape and distribution of ridges and tubercles as seen in Sagittiformosus carabus Bishop, 1988, based on a small, incomplete specimen (Fig. 8.17) from the Cenomanian Frontier Formation of Wyoming, USA. (Ryer, 1977; Holtzclaw, 1987; Bishop, 1988; Winn, 1991; Bhattacharya and Willis, 2001). This specimen should be now considered as a member of Cenomanocarcinus (R. Feldmann, personal communication), based on the presence of three longitudinal tuberculated ridges, two (out of four) transverse tubercles on anterior portion of carapace and straight posterior margin

The stratigraphic and paleobiogeographic range of Cenomanocarcinus is extended to the Campanian in America. Cenomanocarcinus cristatus (Jux, 1971), included in that genus by Guinot et al. (2008), was reported from the upper Campanian of Afghanistan, but the age for the Gholaman Formation is not well constrained. Jux (1971) attributed a Campanian age for that stratigraphic unit based on doubtful identifications of ammonites. The age for the Gholaman Formation needs to be reviewed (A. Shani, personal communication).

Family Orithopsidae Schweitzer, Feldmann, Fam, 
Hessin, Hetrick, Nyborg and Ross, 2003

Emended diagnosis. Carapace medium to large, sub-hexagonal; orbitofrontal margin half the length of carapace; orbits wide; interior and exterior orbital margins with three small triangular spines; anterolateral margins concave, with four triangular spines; posterolateral margin inclined about 45 degrees from posterior margin; posterior margin nearly straight, half maximum carapace width; three longitudinal ridges on dorsal carapace; cervical and branchiocardiac grooves distinct, curved nearly parallel to each other; gastric region subdivided in subrectangular urogastric portion with rhomboidal metagastric region; hepatic region small; cardiac region elongate; branchial region divided into narrow epibranchial portions; intestinal area flat, wide; surface of carapace covered by uniformly distributed small granules and some large tubercles; sternite 1 small, subpentagonal; sternite 2 inverted triangle; sternite 3 subtrapezoidal; sternite 4 the widest of all; sternite 5 of about the same shape as sternite 4 , but one-third shorter and narrower; sternite 6 one-third the width of sternite 5 and one-third longer; sternite 7 one-third smaller than sternite 6.

Discussion. Schweitzer et al. (2003) included the Orithopsidae in the Dorippoidea MacLeay, 1838, based mainly on position of last pereiopods, and on previous interpretations of Glaessner (1969) who referred Orithopsis to the Dorippidae MacLeay, 1838. As no mention of venter or legs existed in the diagnosis of the family given by Schweitzer et al. (2003) and Števčić (2005), Guinot et al. (2008) questioned this placement. Of the six genera (Cherpiocarcinus Maragnon and De Angeli, 1997; Goniochele Bell, 1858; Marycarcinus Schweitzer, Feldmann, Fam, Hessin, Hetrick, Nyborg and Ross, 2003; Orithopsis; Paradoxicarcinus Schweitzer, Feldmann, Fam, Hessin, Hetrick, Nyborg and Ross, 2003; and Silvacarcinus Collins and Smith, 1993) included by Schweitzer et al. (2003) in the Orithopsidae, only Silvacarcinus has clear heterotreme affinities, based on vulva position (Collins and Smith, 1993). Guinot et al. (2008) considered relationships of Cherpiocarcinus with the Dorippoidea as problematic, due to anterior ornament of carapace. Several differences in carapace shape, spines on anterior margin, grooves and development of regions in the dorsal carapace, were considered as features that separate Paradoxicarcinus from the cenomanocarcinids and the necrocarcinids (Guinot et al., 2008). Although Collins and Jakobsen (2003, p. 71) suggested affinities of Goniochele with the Calappoidea de Haan, 1841, dorsal position of P4 and P5 along with morphology of sternites on well-preserved specimens of G. madseni Collins and Jakobsen, 2003, from the Lower Eocene of Denmark (Collins and Jakobsen, 2003), indicate its attribution to the Dorippoidea (Guinot et al., 2008). A non-eubrachyuran condition for Orithopsis was suggested by Guinot et al. (2008, p. 708), based on morphology of sternites 4 and 5 of a specimen of $O$. tricarinata deposited at the Institut Royal des Sciences Naturelles de Belgique, Brussels. Thus, the Orithopsidae should only contain for the moment the type genus, with sternum morphology as the main feature to suggest a close relationship with the Raninoida.

Genus Orithopsis Carter, 1872

Type species. Orithopsis bonneyi Carter, 1872 by monotypy.

Orithopsis tricarinata (Bell, 1863)

Figure 8.18-8.23

Orithya labeschii Deslongchamps, 1835, p. 40, pl. 1, fig. 9.

Necrocarcinus tricarinatus Bell, 1863, p. 21, pl. 4, figs. 9-11; Woodward, 1868, p. 259, pl. 14, fig. 4; Wright and Collins, 1972, p. 66 , pl. 12 , figs. $3-6$, pl. 13, figs. $1-3$; Ilyin, 2005, p. 202, pl. IX, fig. 5.

Orithopsis Bonneyi Carter, 1872, p. 529, pl. 13, fig. 1.

Dakoticancer olssoni Rathbun, 1937, p. 26, pl. 5, fig. 6.

Necrocarcinus olssoni (Rathbun, 1937); Feldmann, Villamil, and Kauffman, 1999, p. 91.

Orithopsis tricarinatus (Bell); Förster, 1968, p. 178; Larghi and Garassino, 2000, p. 54.

Orithopsis tricarinata (Bell); Guinot, Vega and Van Bakel, 2008, p. 63, fig. 9E.

Emended description. Carapace medium to large, sub-hexagonal. Orbitofrontal margin half the length of carapace. Rostrum long, bifid, with two distal sharp spines directed downwards. Orbits wide, shallow, abruptly directed straight up. Interior and exterior orbital margins with three small triangular spines; larger spine on external margin. Anterolateral margins concave, possessing four relatively large triangular spines. First spine smallest, located about 10 $\mathrm{mm}$ from external orbital spine; two medial spines of about equal size, curved toward front; fourth spine the largest, laterally directed, represents border between anterolateral and posterolateral margins, where maximum width of carapace is located. Total length of anterolateral margin about one-half maximum carapace length. Posterolateral margin inclined, about 45 degrees from posterior margin, as long as anterolateral margin. Posterior margin nearly straight, about half maximum carapace width, slightly convex, with elevated rim.

Three longitudinal ridges clearly visible on dorsal carapace surface. Middle ridge located at central axis of carapace, extending from mesogastric region to base of rostrum. Two lateral ridges about the same length, symmetrically located to each side of middle ridge, extending from posterolateral edge of carapace to branchiocardiac grooves.

Cervical and branchiocardiac grooves distinct, curved nearly parallel to each other; maximum depth found at middle portion of carapace. Cervical groove uniformly deep along entire length, slightly wider than branchiocardiac groove, separating protogastric and epigastric regions, terminating at anterolateral margin, between first and second anterolateral spines. Branchiocardiac groove located at central portion of carapace, weakly curved, terminating 
between third and fourth spines of anterolateral margin, separating epi- and mesobranchial regions.

Gastric region subdivided in subrectangular urogastric portion with rhomboidal metagastric, narrow triangular mesogastric and subtriangular protogastric regions. Hepatic region small. Cardiac region elongate. Branchial region divided into narrow epibranchial portions; meso- and metabranchial regions separated by longitudinal ridge. Intestinal area flat, wide.

Surface of carapace covered by uniformly distributed small granules and some large tubercles. One tubercle located at base of mesogastric region, two other tubercles on each protogastric region, approximately level with mesogastric tubercle, separated about $5.0 \mathrm{~mm}$ from each other, and about $5.5 \mathrm{~mm}$ from middle ridge. Additional tubercle occupies anterior portion of urogastric region, another tubercle on anterior portion of cardiac region, and other large tubercles on each mesobranchial region, near flexion point of branchiocardiac groove.

Sternite 1 not seen; sternite 2 inverted triangle; sutures $2 / 3$ not clear; sternite 3 subtrapezoidal, nearly three times as wide and four times as long as sternite 2 ; sutures $3 / 4$ well defined; sternite 4 the widest of all, with inclined, ovate external margins, one-third wider and of about the same length of sternite 2; sutures 4/5 well defined; sternite 5 of about the same shape as sternite 4 , but one-third shorter and narrower; sutures 5/6 well-defined, half the width of preceding sutures; sternite 6 one-third the width of sternite 5 and one-third longer, external portions inverted-triangular; sutures 6/7 deeply impressed, sinuous; sternite 7 one-third smaller than sternite 6 , lateral portions ovate, inclined posteriorly.

Material examined. Five specimens, deposited in the collection of the Burke Museum of Natural History and Culture, University of Washington, Seattle, Washington, USA, under acronym UWBM; hypotypes UWBM 98678 to UWBM 98682; and one specimen USNM 495104 deposited in the National Museum of Natural History, Smithsonian Institution, Washington, DC.

Occurrence. Upper Albian, Hudspeth Formation, Oregon, USA; upper Aptian, Paja Formation, Colombia.

Measurements (in mm). Hypotypes UWBM 98678 carapace width $=26.8$; UWBM 98679 carapace length $=$ 23.7, width $=24.3$; UWBM 98680 carapace length $=26.2$, width $=28.3$; UWBM 98681 carapace length $=22.3$, width $=$ 25.1; UWBM 98682 carapace width = 22.0; USNM 495104 carapace length $=18.1$, width 22.2.

Discussion. Although the Orithopsidae was previously included in the Dorippoidea (Schweitzer et al., 2003; Schweitzer and Feldmann, 2005), Guinot et al. (2008) suggested its inclusion next to the raninoid Paleocorystidae, based on primitive features of sternum. The suspected non-eubrachyran condition of this species suggested by Guinot et al. (2008) is reinforced by the structure of the sternum figured (Guinot et al., 2008, fig. 9F), which is very similar to that observed in Cenomanocarcinus.
However, differences in dorsal carapace suggest that the Orithopsidae should remain as a separate family, related to the Cenomanocarcinidae and Necrocarcinidae, and should be included in the Raninoida.

Dakoticancer olssoni Rathbun, 1937 was synonymized with Necrocarcinus by Feldmann et al. (1999, p. 91). The single known specimen (Figure 8.23) is from Lower Cretaceous of Colombia. It occurs in upper Albian sediments of the Paja Formation (F. Etayo, personal communication) and should be considered a synonym of Orithopsis tricarinata. The species had a very wide distribution, including Ukraine, England, Oregon, and Colombia (Figure 9, Table 1).

There is an important variation of sizes for the specimens reported from different localities. For example, the specimen illustrated by Ilyin (2005) is twice the size of the specimens from Oregon, while specimens figured by Wright and Collins (1972) are of about the same size as the specimens from Oregon. The projected anterior spines are not seen in any of the Oregon specimens, or in the specimen illustrated by Ilyin (2005). Their absence may be due to incomplete preservation, or possible sexual dimorphism.

\section{Conclusions}

Several decapod crustacean species had a wide distribution during Aptian-Albian times. In particular, Orithopsis tricarinata extended from the Crimean Peninsula region to England, Oregon and Colombia (Figure 9). Cenomanocarcinus vanstraeleni was present in Colombia and Oklahoma, and C. renfroae was also distributed from Texas to Colombia. C. vanstraeleni is fairly common in Cenomanian and Turonian deposits from Colombia, Mexico and the SE United States. The species has a wide range of morphologic variation, reflected in overall size, shape of anterolateral spines, size and ornament of chelipeds, sternum and abdomen. Thus, it is important to determine those variations, in order to determine whether they really represent intraspecific variation, or if several species were present at the same time in the same geographic areas. Variation in size and cheliped morphology has been observed in specimens from the Turonian of Colombia and Mexico, suggesting that they may be related to environmental stress. Interpreted paleoenvironments for the Turonian localities of Colombia and Mexico indicate an anoxic bottom of relatively deep seas (Feldmann et al., 1999; Stinnesbeck et al., 2005; Vega et al., 2007, among others). Morphology of chelipeds and pereiopods for this species suggests either an infaunal or swimming crab, with sharp chelipeds typical of a carnivorous and or/scavenger (Guinot et al., 2008). Relatively large numbers of crabs of this species found in ventral position in the same layers indicate mass mortality events (Feldmann et al., 1999; Vega et al., 2007). Thus, environmental stress should have played an important role in the morphological variation of this and other species. 


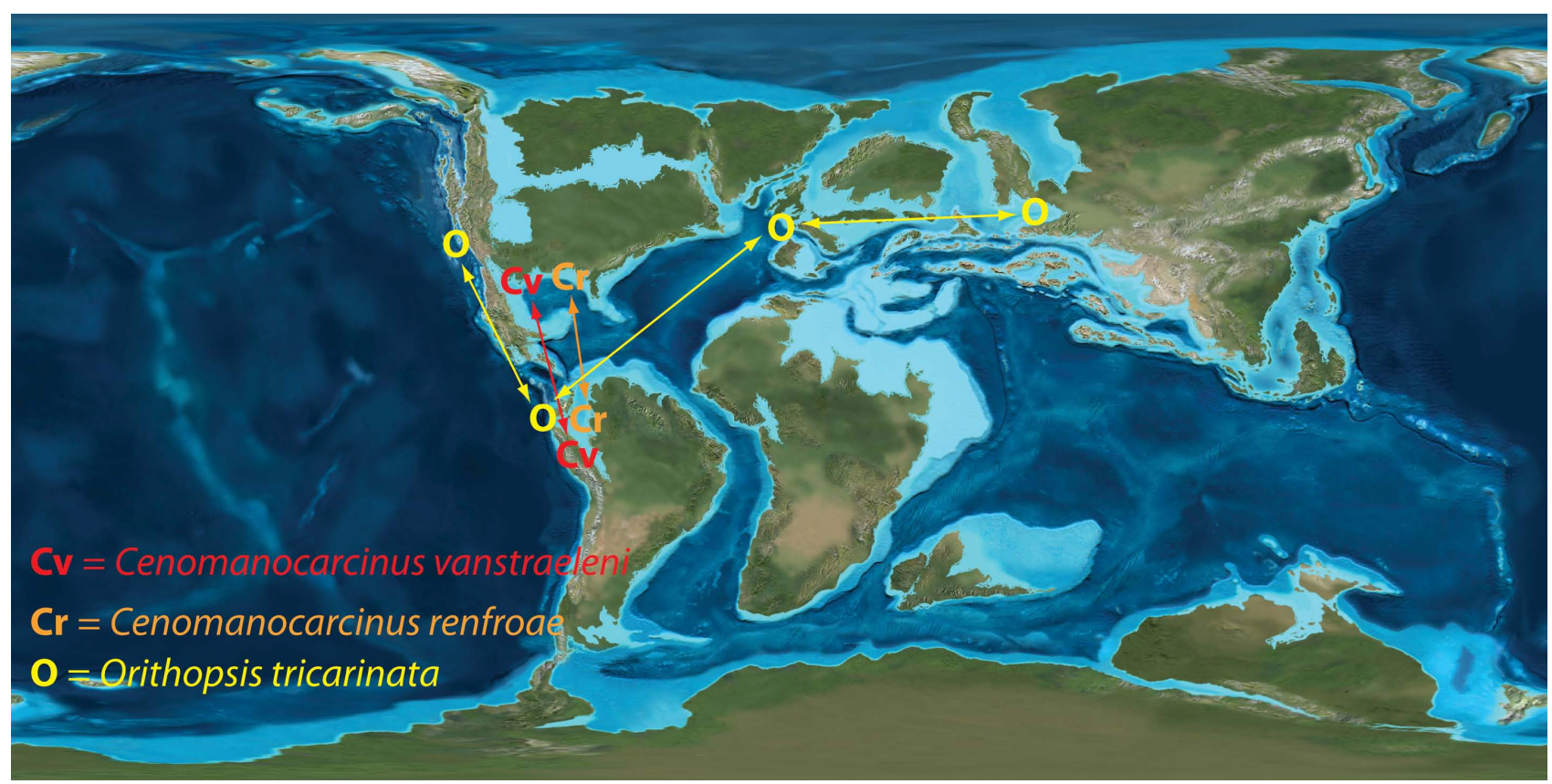

Figure 9. Late Aptian-late Albian paleogeographic map, showing occurrences of taxa here reported and possible migratory routes. Image courtesy of R.C. Blakely.

Table 1. Stratigraphic and geographic distribution for Cenomanocarcinus spp. and Orithopsis tricarinata.

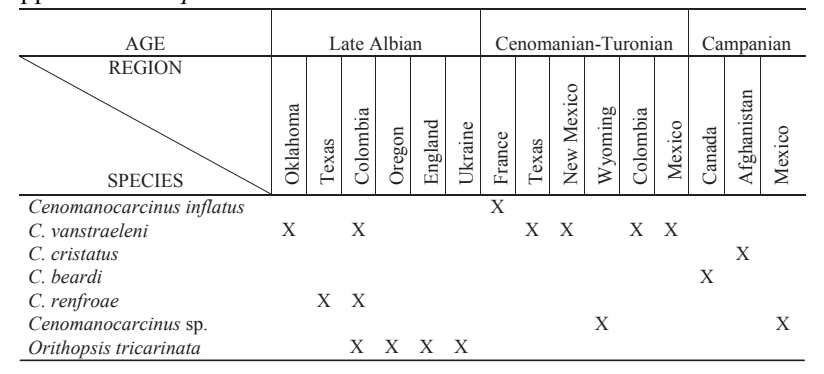

However, Cenomanocarcinus had a wide distribution in America, with the northernmost representative being $C$. beardi Schweitzer, Feldmann, Fam, Hessin, Hetrick, Nyborg and Ross, 2003, from the Upper Cretaceous of British Columbia, Canada. The genus persisted from late Albian to Campanian times in the Tethyan realm (Table 1).

\section{Acknowledgments}

J. F. Osorno of INGEOMINAS, Bogotá, collected and provided important specimens for this study. D. Montoya and G. Reyes, INGEOMINAS, Bogotá, offered logistic support. Some photographs were generously given by Ann Molineaux (Texas Natural Science Center, Austin). C. Ifrim and A. Shani provided important stratigraphic information. Alex Tate, Geological Data Manager, British Antarctic
Survey, provided images to document this contribution. Our sincere gratitude to Christiano Larghi for his advice, and to Alessandro Garassino, Museo di Storia Naturale, Milano, Italy, who provided images of several specimens. Ronald C. Blakely, Northern Arizona University, generously provided several paleogeographic maps. Special thanks to Rodney M. Feldmann and Hiroaki Karasawa for their valuable suggestions to improve the original manuscript. Support of Jann Thompson of the National Museum of Natural History is highly appreciated. Elena Lounejeva provided translations from Russian to complete the descriptions of genera.

\section{References}

Acosta, C.E., Huertas, G., Ruiz, P.M., 1979, Noticia preliminar sobre el hallazgo de un presunto Kronosaurus (Reptilia: Dolychorynchopidae) en el Aptiano Superior de Villa de Levia, Columbia: Lozania (Acta Zoologica Columbiana), 28, 1-10.

Adkins, W.S., 1918, The Weno and Paw Paw formations of the Texas Comanchean: University of Texas Bulletin, 1856, 1-172.

Barrero, D., Pardo, A., Vargas, C.A., Martínez, J.F., 2007, Colombian Sedimentary Basins: Nomenclature, Boundaries and Petroleum Geology, a new proposal: Bogotá, Colombia, Agencia Nacional de Hidrocarburos (ANH), $91 \mathrm{p}$.

Bell, T., 1858, A Monograph of the fossil malacostracous Crustacea of Great Britain. Part I. Crustacea of the London Clay: London, Palaeontographical Society, $44 \mathrm{p}$.

Bell, T., 1863, A Monograph of the fossil malacostracous Crustacea of Great Britain, Part II. Crustacea of the Gault and Greensand: London, Palaeontographical Society, $40 \mathrm{p}$.

Bhattacharya, J.P., Willis, B.J., 2001, Lowstand Deltas in the Frontier Formation, Powder River Basin, Wyoming: Implications for Sequence Stratigraphic Models: American Association of Petroleum Geologists Bulletin, 85, 261-294. 
Bishop, G.A., 1986, Occurrence, preservation, and biogeography of the Cretaceous crabs of North America, in Gore, R.H., Heck, K.L. (eds.), Crustacean Issues Vol. 4 Crustacean Biogeography: Boston, Balkema Press, 111-142.

Bishop, G.A., 1988, New fossil crabs, Plagiophthalmus izetti, Latheticocarcinus shapiroi, and Sagittiformosus carabus (Crustacea, Decapoda) from the Western Interior Cretaceous, USA.: Proceedings of the Biological Society of Washington, 101, 375-381.

Bishop, G.A., Brannen, N.A., Hill, L.E., Meyer, J. P., Pike, A.J., Sampson, C., 1992, The Britton Notopocorystes assemblage: an Eagle Ford decapod assemblage from the Cretaceous of North-Central Texas, in Transactions of the 42nd Annual Convention: Jackson, Massachusetts, USA, Gulf Coast Association of Geological Societies, 413-424.

Blake, D.B., Reid, R., 1998, Some Albian (Cretaceous) asteroids (Echinodermata) from Texas and their paleobiological implications: Journal of Paleontology, 72, 512-532.

Bürlg, H., 1954, El Cretáceo inferior en los alrededores de Villa de Leiva (Boyacá): Boletín Geológico del Instituto Geológico Nacional, 2, 5-22.

Carter, J., 1872, On Orithopsis bonneyi, a new fossil crustacean: Geological Magazine, 9, 529-532.

Collins, J.S.H., Jakobsen, S.L., 2003, New crabs (Crustacea, Decapoda) from the Eocene (Ypresian/Lutetian) Lillebaelt Clay Formation of Jutland, Denmark: Bulletin of the Mizunami Fossil Museum, 30, 63-95.

Collins, J.S.H., Smith, R., 1993, Ypresian (Lower Eocene) crabs (Decapoda, Crustacea) from Belgium: Bulletin de l'Institut royal des Sciences naturelles de Belgique, Sciences de la Terre, 63, 261-270.

Deslongchamps, J.A.E., 1835, Mémoire pour servir à l'histoire naturelle des Crustacés fossiles: Mémoires de la Société Linnéenne de Normandie, 5, 37-46.

Dorsey, R.J., Lenegan, R.J., 2007, Structural controls on middle Cretaceous sedimentation in the Toney Butte area of the Mitchell inlier, Ochoco basin, central Oregon, in Cloos, M., Carlson, W.D., Gilbert, M.C., Liou, J.G., Sorensen, S.S. (eds.) Convergent margin terranes and associated regions: a tribute to W.G. Ernst: Austin, Texas, USA, The Geological Society of America Special Paper 419, 97-115.

Etayo-Serna, F., 1968, El Sistema Cretáceo en la región de Villa de Leiva y zonas próximas: Geología Colombiana, 5, 5-74.

Etayo-Serna, F., 1979, Zonation of the Cretaceous of Central Colombia by Ammonites: Bogotá, Colombia, INGEOMINAS, Publicación Especial 2, $186 \mathrm{p}$

Etayo-Serna, F., Barrero, D., Lozano, H., Espinosa, A., González, H., Orrego, A., Ballesteros, I., Forero, H., Ramírez, C., Zambrano, F., Duque, H., Vargas, R., Núñez, A., Álvarez, J., Ropain, C., Cardoso, E., Galvis, N., Sarmiento, L., 1986, Mapa de terrenos geológicos de Colombia: Bogotá, Colombia, INGEOMINAS, Publicación Especial 14, 235 p.

Feldmann, R.M., Villamil, T., Kauffman, E.G., 1999, Decapod and stomatopod crustaceans from mass mortality Lagerstatten: Turonian (Cretaceous) of Colombia: Journal of Paleontology, 73, 91-101.

Finsley, C., 1989, A Field Guide to Fossils of Texas: Austin, Texas, Texas Monthly Press, $188 \mathrm{p}$.

Förster, R., 1968, Paranecrocarcinus libanoticus n. sp. (Decapoda) und die Entwicklung der Calappidae in der Kreide: Mitteilungen der Bayrischen Staatssammlung Paläontologische Historische Geologie, $8,167-195$

Fraaije, R.H.B., Vega, F.J., Van Bakel, B.W.M., Garibay-Romero, L.M., 2006, Late Cretaceous dwarf decapods from Guerrero, southern Mexico and their migration patterns: Contributions to Zoology, $75,121-132$.

Glaessner, M.F., 1969, Decapoda, in Moore, R.C. (ed.), Treatise on Invertebrate Paleontology, Part R, Arthropoda. Lawrence, Kansas, USA, University of Kansas Press, R399-R533, R626-R628.

Guinot, D., Vega, F.J., Van Bakel, B.W.M., 2008, Cenomanocarcinidae n. fam., a new Cretaceous podotreme family (Crustacea, Decapoda, Brachyura, Raninoidia) with comments on related families:
Geodiversitas, 30, 681-719.

Haan, W., 1833-1850, Crustacea, in Siebold, P.F. (ed.), Fauna Japonica sive Descriptio animalium, quae in itinere per Japoniam, jussu et auspiciis superiorum, qui summum in India Batava Imperium tenent, suscepto, annis 1823-1830 collegit, notis, observationibus et adumbrationibus illustravit Ph. Fr. De Siebold, i-xvii, i-xxxi, ix-xvi, 1-243: Leiden, J. Müller et Co., 109-164.

Haj, A.E., Feldmann, R.M., 2002, Functional morphology and taxonomic significance of a novel cuticular structure in Cretaceous raninid crabs (Decapoda: Brachyura: Raninidae): Journal of Paleontology, $76,472-485$.

Hendricks, L., 1967, Comanchean stratigraphy of the Cretaceous of north Texas in Hendricks, L. (ed.), Comanchean (Lower Cretaceous) Stratigraphy and Paleontology of Texas: Society of Economic Paleontology and Mineralogy Publication, 67-8, 51-63.

Hill, R.T., 1894, Geology of parts of Texas, Indian Territory, and Arkansas adjacent to the Red River: Bulletin of the Geological Society of America, 5, 297-338.

Holtzclaw, S.R., 1987, Stratigraphy and sedimentology of the Lower Frontier Formation (Cretaceous), southwestern Bighorn Basin, Wyoming: El Paso, Texas, USA, The University of Texas, Masters of Science Thesis, $224 \mathrm{p}$.

Ilyin, I.V., 2005, Melovye i paleogenovye desiatinogie rakoobraznye (Crustaceomorpha, Decapoda) zapadnoii chasti Severnoi Evrazii Cretaceous and Paleogene decapod crustaceans of the western part of Northern Eurasia]: Moscow, Russia, Izdatel'stvo Moskovskogo Universiteta, $295 \mathrm{p}$.

Jerez-Jaimes, J.H., Narváez-Parra, E.X., 2001, Callawayasaurus colombiensis (Welles) Carpenter, 1999. El plesiosaurio de Villa de Leiva (Boyacá, Colombia) ¿Un nuevo espécimen?: Boletín de Geología de la Universidad Industrial de Santander, 23, 9-19.

Jux, U., 1971, Ein Brachyuren-Rest aus der Oberkreide Afghanistans: Paläontologische Zeitschrift, 45, 154-166.

Kennedy, W.J., 2004, Ammonites from the Pawpaw Shale (Upper Albian) in northeast Texas: Cretaceous Research, 25, 865-905.

Kennedy, W.J., Cobban, W.A., Hancock, J.M., Gale, A.S., 2005, Upper Albian and lower Cenomanian ammonites from the Main Street Limestone, Grayson Marl and Del Rio Clay in northeast Texas: Cretaceous Research, 26, 349-428.

Kleinhans, L.C., Barcells-Baldwin, E.A., Jones, R.E., 1984, A paleogeographic reinterpretation of some middle Cretaceous units, north-central Oregon: Evidence for a submarine turbidite system, in Nilsen, T.H. (ed.), Geology of the upper Cretaceous Hornbrook Formation, Oregon and California: Los Angeles, California, USA, Pacific Section SEPM, 42, 239-257.

Kues, B.S., 1980, A fossil crab from the Mancos Shale (Upper Cretaceous) of New Mexico: Journal of Paleontology, 54, 862-864.

Larghi, C., Garassino, A., 2000, The brachyurans of the Cenomanian (Upper Cretaceous) of Lebanon, in 1st Workshop on Mesozoic and Tertiary Decapod Crustaceans: Montecchio Maggiore, Vicenza, Italy, Studi e Ricerche, Associazione Amici del Museo-Museo Civico "G. Zannato", 53-54.

Latreille, P.A., 1802, Histoire naturelle, générale et particulière, des crustacés et des insectes, Volume 3. Familles naturelles des genres: Paris, France, Dufart, $467 \mathrm{p}$

Lee, Y.N., 1994, The early Cretaceous pterodactyloid pterosaur Coloborhynchus from North America: Palaeontology, 37, 755-763.

Lee, Y.N., 1996, A new nodosaurid ankylosaur (Dinosauria: ornithischia) from the Paw Paw Formation (late Albian) of Texas: Journal of Vertebrate Paleontology, 16, 232-245.

MacLeay, W.S., 1838, On the Brachyurous Decapod Crustacea brought from the Cape by Dr. Smith, in Smith, A. (ed.), Illustrations of the Annulosa of South Africa; being a portion of the objects of Natural History chiefly collected during an expedition into the interior of South Africa, under the direction of Dr. Andrew Smith, in the years 1834, 1835 and 1836; fitted out by "The Cape of Good Hope Association for Exploring Central Africa": London, Smith, Elder and Co., 53-71. 
Marangon, S., De Angeli, A, 1997, Cherpiocarcinus, nuovo genere di brachiuro (Decapoda) dell'Oligocene del bacino ligure-piemontese (Italia settentrionale): Lavori Società Veneziana di Scienze Naturali, 22, 97-106.

McGowen, J.H., Jr., Proctor, C.V., Haenggi, W.T., Reaser, D.F., Barnes, V.E., 1972, Geologic Atlas of Texas, Dallas Sheet, scale 1:250 000: Austin, Texas, USA, Bureau of Economic Geology-The University of Texas at Austin, 1 map.

McKnight, B.K., 1964, A stratigraphic study of the marine Cretaceous rocks near Mitchell, Oregon: Corvallis, Oregon, USA, Oregon State University, Masters of Science Thesis, $89 \mathrm{p}$.

Morales, L.G., Podesta, D.J., Hatfield, W.C., Tanner, H., Jones, S.H., Barker, M.H., O’Donoghue, D.J., Mohler, C.E., Dubois, E.P., Jacobs, C., Goss, C.R., 1958, General geology and oil ocurrence of the Middle Magdalena Valley, Colombia, in Weeks, L.G. (ed.), Habitat of Oil A Symposium: Tulsa, Oklahoma, USA, American Association of Petroleum Geologists, 641-695.

Nilsen, T.H., 1986, Cretaceous Paleogeography of Western North America, in Abbott, P.L. (ed.), Cretaceous Stratigraphy of Western North America: Los Angeles, California, USA, Pacific Section SEPM, $1-39$

Oles, K.F., Enlows H.E., 1971, Bedrock geology of the Mitchell quadrangle, Wheeler County: Portland, Oregon, USA, Oregon Department of Geology and Mineral Industry Bulletin 72, $62 \mathrm{p}$.

Patarroyo, P., 2004, Die Entwicklung der Ammoniten der Familie Pulchelliidae aus dem Barrême von Zentral-Kolumbien: Revue de Paléobiologie, 23, 1-65.

Patarroyo, P., Rojas-Briceño, A., 2007, La sucesión y la fauna del Turoniano de la Formación San Rafael en Pesca y su comparación con la sección tipo en Samacá (Boyacá-Colombia-S.A.): Geología Colombiana, 32, 89-96.

Petters, V., 1954, Tertiary and Upper Cretaceous Foraminifera from Colombia: Cushman Foundation for Foraminiferal Research Contributions, 5, 37-41.

Rathbun, M.J., 1935, Fossil Crustacea of the Atlantic and Gulf Coastal Plain: Geological Society of America Special Papers, 2, 1-160.

Rathbun, M.J., 1937, Cretaceous and Tertiary crabs from Panama and Colombia: Journal of Paleontology, 11, 26-28.

Roger, J., 1946, Les invertébrés des couches à poissons du Crétacé supérieur du Liban. Étude paléobiologique des gisements: Mémoires de la Société géologique de France, 23, 1-92.

Root, S.A., 1975, Lithofacies and depositional environments of the Weno and Pawpaw formations (Lower Cretaceous) of north-central Oklahoma: Arlington, Texas, USA, University of Texas at Arlington, Masters Thesis, $114 \mathrm{p}$.

Royero, J.M., Clavijo, J., 2001, Mapa Geológico del Departamento de Santander, Escala 1:400 000: Bucaramanga, Colombia, INGEOMINAS, 1 map with text, $92 \mathrm{p}$.

Ryer, T.A., 1977, Age of Frontier Formation in north-central Utah: American Association of Petroleum Geologists Bulletin, 61, 112116.

Schweitzer, C.E., Feldmann, R.M., 2001, New Cretaceous and Tertiary decapod crustaceans from western North America: Bulletin of the Mizunami Fossil Museum, 28, 173-210.
Schweitzer, C.E., Feldmann, R.M., 2005, Decapod crustaceans, the K/P event, and Palaeocene recovery in Koenemann, S., Jenner, R.A. (eds.), Crustacean Issues 16. Crustacea and Arthropod relationships: Boca Raton, Florida, USA, Taylor and Francis Group: 17-53.

Schweitzer, C.E., Feldmann, R.M., Fam, J., Hessin, W.A., Hetrick, S.W., Nyborg T.G., Ross, L.M., 2003, Cretaceous and Eocene decapod crustaceans from Southern Vancouver Island, British Columbia, Canada: Ottawa, Ontario, Canada, NRC Research Press, 66 p.

Schweitzer Hopkins, C., Salva, E.W., Feldmann, R.M., 1999, Re-evaluation of the genus Xanthosia Bell, 1863 (Decapoda: Brachyura: Xanthidae) and description of two new species from the Cretaceous of Texas: Journal of Paleontology, 73, 77-90.

Siverson, M., Lindgren, J., Kelley, L.S., 2007, Anacoracid sharks from the Albian (Lower Cretaceous) Pawpaw Shale of Texas: Palaeontology, $50,939-950$.

Stenzel, H.B., 1945, Decapod crustaceans from the Cretaceous of Texas: The University of Texas Publication, 4401, 401-477.

Števčić, Z., 2005, The reclassification of brachyuran crabs (Crustacea: Decapoda: Brachyura): Natura Croatica, 14, 1-159.

Stinnesbeck, W., Ifrim, C., Shmidt, H., Rindfleisch, A., Buchy, M.C., Frey, E., González-González, A.H., Vega, F.J., Cavin, L., Keller, G., Smith, K.T., 2005, A new lithographic limestone deposit in the Upper Cretaceous Austin Group at El Rosario, county of Muzquiz, Coahuila, northeastern México: Revista Mexicana de Ciencias Geológicas, 22, 401-418.

Toolson, E.K., Kues, B.S., 1996, Decapod crustaceans from the Semilla Sandstone Member, Mancos Shale (Upper Cretaceous), NorthCentral New Mexico: Journal of Paleontology, 70, 111-116.

Van Straelen, V., 1936, Crustacés décapodes nouveaux ou peu connus de l'époque Crétacique: Bulletin du Musée Royal d'Histoire Naturelle de Belgique, 12, 1-49.

Vega, F.J., Nyborg, T., Rojas-Briceño, A., Patarroyo, P., Luque, J., PorrasMúzquiz, H., Stinnesbeck, W., 2007, Upper Cretaceous Crustacea from Mexico and Colombia: common faunas and evironments during Turonian times: Revista Mexicana de Ciencias Geológicas, $24,403-422$.

Ward, D., Goldsmith, R., Cruz, J., 1973, Geología de los cuadrángulos H-12 Bucaramanga y H-13 Pamplona, Departamento de Santander: INGEOMINAS Boletín Geológico, 21, 1-3.

Wilkinson, W.D., Oles, K.F., 1968, Stratigraphy and paleoenvironments of Cretaceous rocks, Mitchell Quadrangle, Oregon: American Association of Petroleum Geologists Bulletin, 52, 129-161.

Winn, R.D., 1991, Storm deposition in marine sand sheets; Wall Creek Member, Frontier Formation, Powder River basin, Wyoming: Journal of Sedimentary Research, 61, 86-101.

Woodward, H., 1868, Contributions to British fossil Crustacea: Geological Magazine, 5, 258-261.

Wright, C.W., Collins, J.S.H., 1972, British Cretaceous Crabs: Palaeontographical Society Monographs, 126, 1-113.

Manuscript received: December 7, 2009.

Corrected manuscript received: April 1, 2010.

Manuscript accepted: April 12, 2010. 